\title{
Jurist-Diction
}

Volume 4 No. 1, Januari 2021

\section{Implementasi Teknik Pembelian Terselubung dan Penyerahan di Bawah Pengawasan Penyidikan Dalam Pemberantasan Tindak Pidana Narkotika}

\author{
Radytya Bagus Bimoaji \\ radityabimo14@gmail.com \\ Universitas Airlangga
}

\begin{abstract}
How to cite:
Radytya Bagus Bimoaji,

'Implementasi Teknik

Pembelian Terselubung

Dan Penyerahan Di Bawah

Pengawasan Penyidikan Dalam

Pemberantasan Tindak Pidana

Narkotika' (2021) Vol. 4 No. 1

Jurist-Diction.
\end{abstract}

Histori artikel:

Submit 1 Oktober 2020;

Diterima 12 November 2020;

Diterbitkan 5 Januari 2021.

DOI:

10.20473/jd.v4i1.24303

p-ISSN: $2721-8392$

e-ISSN: 2655-8297

\begin{abstract}
The circulation of narcotics is increasing from time to time. Narcotics is considered a serious crime in its handling. Considering that narcotics is a serious crime, provisions that regulate special techniques are needed in order to resolve narcotics cases fairly, quickly and efficiently. Based on this background, problems were formulated regarding the basis for the regulation of covert purchasing techniques and supervised delivery and the implications of using covert purchasing techniques and supervised delivery. To answer these problems, a statute approach and a conceptual approach are used. With this approach to the problem, an answer is obtained that the legal consideration of the stipulation of covert purchasing techniques and submission under supervision is to facilitate the investigation and prosecution of people involved in narcotics criminal cases. Considering that narcotics is a serious crime and it is quite difficult to disclose it, the use of covert purchasing techniques and supervised delivery can become a basis for consideration in criminal case investigations. The impact of using covert purchase investigative techniques and supervised submission comes from juridical and social impacts. The juridical impact of these two techniques is that the legal certainty of these two techniques is valid for the investigators. However, the social impact of using these two techniques is that there is a concern that the abuse of the authority of investigators and the rights of narcotics suspects has the potential to be violated, so that the role of the community according to what is stipulated in the Narcotics Law can be implemented and the implementation of narcotics settlement can be implemented quickly and fairly.

Keywords: Implementation; Undercover Buy; Control Delivery.
\end{abstract}

\begin{abstract}
Abstrak
Peredaran narkotika semakin meningkat dari waktu ke waktu. Narkotika dianggap suatu kejahatan yang serius dalam penanganannya. Mengingat narkotika adalah kejahatan yang serius, diperlukan ketentuan yang mengatur teknik khusus guna penyelesaian kasus narkotika secara adil, cepat dan efisien. Berdasarkan latar belakang tersebut dirumuskan permasalahan mengenai dasar pertimbangan diaturnya teknik pembelian terselubung dan penyerahan di bawah pengawasan dan implikasi dari penggunaan teknik pembelian terselubung dan penyerahan di bawah pengawasan. Untuk menjawab permasalahan tesebut digunakan pendekatan masalah perundang-
\end{abstract}




\begin{abstract}
undangan (statute approach) dan pendekatan konsep (conceptual approach). Dengan pendekatan permasalahan tersebut diperoleh jawaban bahwa pertimbangan hukum ditetapkannya teknik pembelian terselubung dan penyerahan di bawah pengawasan adalah untuk mempermudah penyidikan dan penuntutan terhadap orang-orang yang terlibat dalam kasus tindak pidana narkotika. Mengingat narkotika termasuk dalam suatu kejahatan yang serius dan terbilang cukup sulit pengungkapannya, Maka penggunaan teknik pembelian terselubung dan penyerahan di bawah pengawasan dapat menjadi dasar pertimbangan dalam penyidikan kasus tindak pidana. Dampak dari penggunaan teknik penyidikan pembelian terselubung dan penyerahan di bawah pengawasan muncul dampak yuridis dan dampak sosial. Dampak yuridis dari kedua teknik ini adalah kepastian hukum dari kedua teknik ini sah dilakukan oleh penyidik. Namun, dampak sosial dalam penggunaan kedua teknik ini yaitu muncul kekhawatiran penyalahgunaan kewenangan penyidik dan hak-hak tersangka narkotika berpotensi untuk dilanggar, sehingga peran masyrakat sesuai apa yang diatur dalam Undang-Undang Narkotika dapat terlaksana dan tercipta pelaksanaan penyelesaian narkotika secara cepat dan adil. Kata Kunci: Implementasi; Teknik Pembelian Terselubung; Teknik Penyerahan di Bawah Pengawasan.
\end{abstract}

Copyright $(\subset 2021$ Universitas Airlangga

\section{Pendahuluan}

Peredaran narkotika semakin waktu ke waktu semakin marak. Sasaran dari tindak pidana narkotika tidak hanya dari kalangan dewasa melainkan hingga menyentuh kaum remaja dan anak-anak tanpa mengenal dari latar belakang keluarga. Tentunya dengan modus operandi yang berbeda dengan modus operandi yang digunakan untuk menjerat kalangan dewasa. Daerah peredaran gelap narkotika tidak hanya di kota-kota besar, namun sudah memasuki wilayah-wilayah pedesaan. Peredaran narkotika ini akan berkembang seiring dengan zaman. Banyaknya masyarakat Indonesia yang terjerumus kedalam lingkaran jahat narkotika dan membuat pemerintah Indonesia harus melakukan beberapa langkah untuk keluar dari situasi darurat terhadap narkotika. Narkotika dianggap suatu kejahatan yang serius dalam penanganannya. Karena narkotika adalah kejahatan yang serius, diperlukan ketentuan yang mengatur teknik khusus guna penyelesaian kasus narkotika secara adil, cepat dan efisien.

Hukum positif di Indonesia yang mengawasi, mengendalikan penggunaan narkotika dan menanggulangi penyalahgunaan dari narkotika dikenal dengan hukum 
narkotika. ${ }^{1}$ Permasalahan tindak pidana narkotika ini belum dapat diselesaikan dengan tuntas walaupun Negara Indonesia memiliki Undang-Undang No. 5 tahun 1997 tentang Psikotropika dan Undang-Undang Nomor 22 Tahun 1997 tentang Narkotika. Pada oktober 2009, pemerintah telah mengesahkan pengganti undangundang diatas dengan Undang-Undang Nomor 35 tahun 2009 tentang Narkotika. Hal ini melihat dari bahaya dan tingkat peredarannya sehingga Pemerintah menetapkan Undang-Undang Nomor 35 Tahun 2009 diharapkan dapat menekan dan mencegah peredaran serta penggunaan narkotika di Indonesia. Dengan pemberlakuan Undang-Undang No. 35 Tahun 2009, semua pihak yang terlibat dalam pemberantasan narkotika dapat menetapkan secara adil bagi pelaku tindak pidana narkotika karena pengaruh narkotika sangat meluas terhadap kelangsungan hidup bagi generasi penerus bangsa. ${ }^{2}$

Ketentuan mengenai teknik khusus tersebut diatur dalam Pasal 75 huruf J Undang-Undang Nomor 35 Tahun 2009 Tentang Narkotika yaitu teknik penyidikan pembelian terselubung dan penyerahan dibawah pengawasan. Teknik penyidikan pembelian terselubung merupakan suatu teknik khusus dalam penyidikan kegiatan narkotika, dimana seorang informan atau anggota polisi (dibawah selubung) atau pejabat lain yang diperbantukan oleh polisi, bertindak sebagai pembeli dalam suatu transaksi gelap jual beli narkoba, dengan maksud pada saat terjadi hal tersebut, si penjual atau perantara atau orang-orang yang berkaitan dengan peredaran narkoba dapat ditangkap beserta barang bukti yang ada padanya. ${ }^{3}$ Penyerahan dibawah pengawasan adalah sebuah teknik khusus yang dilakukan penyidik tindak pidana narkoba tahap penyelidikan dan terjadi penangguhan/ penangkapan/ penahanan/ penyitaan barang bukti, dimana seorang tersangka yang mau bekerja sama dengan polisi atau informan penerimanya, dengan maksud pada saat penerimaan dapat

\footnotetext{
${ }^{1}$ Hari Sasangka, Narkotika dan Psikotropika dalam Hukum Pidana (Mandar Maju 2003).[4].

2 Frans Simangunsong, 'Penegakan Hukum Terhadap Pelaku Tindak Pidana Narkotika (Studi Kasus di Kepolisian Resor Surakarta)' (2014) 8 Yuridika UNSA.[2].

${ }^{3}$ Rini Friastuti, 'Mengenal Undercover Buying dan Control Delivery Dalam Penanganan Kasus Narkoba', (detikNews, 2016) <https://news.detik.com/berita/d-3317950/mengenal-undercover-buying-dan-control-delivery-dalam-penanganan-kasus-narkoba>, accessed 1 Agustus 2019.
} 
ditangkap orang - orang yang terlibat kejahatan narkoba beserta barang buktinya. ${ }^{4}$

Dalam pelaksanaan penyidikan dengan teknik pembelian terselubung dan penyerahan dibawah pengawasan di lapangan, hendaknya para penyidik harus mempertimbangkan aspek-aspek hak-hak tersangka atau terdakwa. Hal ini perlu digaris bawahi karena terkait dengan kewenangan penyidik yang dianggap sangat yang bergantung pada hasil penilaian penyidik. ${ }^{5}$ Dengan melihat teknik penyidikan pembelian terselubung dan penyerahan dibawah pengawasan sangat subyektif dalam penerapannya, sehingga diperlukan dasar pertimbangan munculnya teknik penyidikan pembelian terselubung dan penyerahan dibawah pengawasan. Pengaturan mengenai penggunaan teknik pembelian terselubung dan teknik penyerahan dibawah pengawasan sudah jelas, namun bagaimana dampak dari penerapan teknik pembelian terselubung dan penyerahan dibawah pengawasan perlu dibedah dari segi yuridis dan sosial. Sehingga, perlu adanya ketentuan dan penegakan hukum yang jelas dan bagaimana dasar pertimbangan berlakunya teknik penyidikan pembelian terselubung dan penyerahan dibawah pengawasan demi kepastian hukum.

\section{Dasar Pertimbangan Penggunaan Teknik Pembelian Terselubung dan Penyerahan di Bawah Pengawasan Dalam Hukum Internasional dan Nasional}

Narkotika termasuk kategori kejahatan luar biasa (extraordinary crime) yang memiliki potensi untuk menghancurkan masa depan anak bangsa. Narkotika merupakan barang yang mudah didapat karena kebutuhan sesaat sebagai efek candu dan kenikmatan tubuh penggunanya. ${ }^{6}$ Tindak pidana narkotika telah dikategorikan sebagai tindak pidana yang unordinary crime, yakni sebagai tindak pidana kejahatan luar biasa. ${ }^{7}$ Tindak pidana narkotika merupakan suatu bentuk

\footnotetext{
${ }^{4}$ ibid.

${ }^{5}$ Riza Alifianto Kurniawan, 'Pencegahan Penyalahgunaan Kewenangan Penyidik Dalam Penegakan Hukum Tindak Pidana Narkotika' (2018) 47 Masalah-Masalah Hukum.[116].

${ }^{6}$ Ade Maria Engelina, 'Penerapan Pembelian Terselubung Dalam Penyelidikan Tindak Pidana Penyalahgunaan Narkotika Oleh Kepolisian Resor Siak', (2018) V JOM Fakultas Hukum.[2].

7 AR. Sujono dan Bony Daniel, Komentar \& Pembahasan Undang-Undang Nomor 35 Tahun 2009 tentang Narkotika, (Sinar Grafika 2011).[32].
} 
kejahatan inkonvensional yang dilakukan secara sistematis, dengan menggunakan modus operandi yang sulit, teknologi canggih, dan dilakukan secara terorganisir dan bersifat transnasional yaitu lintas negara. ${ }^{8}$ Kegentingan akan penyebaran narkotika yang semakin meluas membuat negara-negara didunia sepakat untuk membuat konvensi yang diselenggarakan oleh Persatuan Bangsa-Bangsa (United Nation) yang diantaranya yaitu Konvensi Tunggal Narkotika pada tahun 1961 (United Nations Conference for the Adoption of a Single Convention on Narcotic Drugs 1961), Konvensi Psikotropika pada tahun 1971 (Convention of Psychotropic Substance 1971), Konvensi Perserikatan Bangsa-Bangsa Tentang Pemberantasan Peredaran Gelap Narkotika dan Psikotropika pada tahun 1988 (United Nations Convention Aginst Illict Traffic In Narcotics Drugs and Psychotropic Substances 1988), dan Pertemuan negara-negara ASEAN mengenai pencegahan dan kontrol terhadap peredaran narkotika pada tahun 1972 (ASEAN Drugs Experts Meeting On The Prevention and Control of Drug Abuse 1972). Konvensi Perserikatan BangsaBangsa Tentang Pemberantasan Peredaran Gelap Narkotika dan Psikotropika pada tahun 1988 (United Nations Convention Aginst Illict Traffic In Narcotics Drugs and Psychotropic Substances 1988) menjadi dasar pertimbangan yang paling baru dan menjadi dasar dari lahirnya Undang-Undang Narkotika. Kejahatan-kejahatan yang dimuat dalam konvensi ini merupakan jenis-jenis kejahatan yang menurut sistem hukum nasional negara dianggap sebagai tindakan kejahatan yang dapat dituntut dan dipidana. Dalam Pasal 3 ayat (1) Undang-Undang Nomor 7 Tahun 1997, keterlibatan pelaku oknum narkotika melalui kelompok kejahatan terorganisasi secara internasional dapat dikategorikan kedalam kejahatan serius. Sehingga, hal inilah yang menjadi dasar pertimbangan bahwa kasus terkait penyalahgunaan dan peredaran gelap narkotika maupun psikotropika adalah kejahatan transnasional yang sangat serius. Maka, penyalahgunaan narkotika adalah suatu kejahatan yang serius. Kegiatan perbuatan melawan hukum yang dilakukan secara transnasional

\footnotetext{
${ }^{8}$ Heni Hendrawati, Johny Krisnan, Nurwati, 'Analisis Penyidikan Tindak Pidana Penyalahgunaan Narkotika Dan Tindak Pidana Umum Dalam Kajian Perbandingan’ (2019) IX Yuridika Universitas Muhammadiyah Purworejo.[132].
} 
dan kejahatan terorganisasi menjadi perspektif dari tindak pidana narkotika saat ini. Gembong narkotika dari suatu jaringan narkotika menjadi sulit ditangkap. Kemudian tindak pidana narkotika terbilang cukup sulit dalam pengungkapannya karena berupa suatu jaringan/ sindikat yang sangat luas. Oleh karena itu, kedua teknik ini dapat mempermudah jalannya penyidikan dan penuntutan terhadap orangorang yang terlibat dalam kasus tindak pidana narkotika. Mengingat kasus tindak pidana narkotika adalah kejahatan tanpa adanya korban. Hal inilah yang menjadi urgensi penggunaan teknik penyidikan pembelian terselubung dan penyerahan di bawah pengawasan dalam pengungkapan suatu jaringan narkotika yang dilakukan penyidik. Sehingga penyidik tidak hanya menangkap orang-orang yang hanya menjadi kurir ataupun pengguna, namun penyidik dapat menangkap dalang/otak dari persebaran narkotika dari suatu jaringan narkotika tertentu.

\section{Implementasi Teknik Pembelian Terselubung dan Penyerahan Di Bawah Pengawasan}

Teknik pembelian terselubung dan penyerahan di bawah pengawasan dalam kasus tindak pidana narkotika dapat dilakukan oleh institusi Polri yang berpedoman pada Peraturan Kapolri Nomor 6 Tahun 2019 tentang Manajemen Penyidikan Tindak Pidana. Pembelian terselubung dan penyerahan yang diawasi merupakan teknik yang dilakukan oleh penyelidik dalam tindak pidana narkotika dan prekursor narkotika. Pembelian terselubung menurut petunjuk lapangan No. Pol. Juklap/04/VIII/1983 bahwa pembelian terselubung merupakan suatu teknik khusus dalam penyelidikan kejahatan narkotika dan prekursor narkotika, dimana seorang informan atau anggota polisi bekerja dibawah selubung, bertindak sebagai pembeli dalam suatu transaksi jual beli narkotika, dengan tujuan saat terjadi jual beli si penjual atau perantara atau orang-orang yang berkaitan dengan peredaran narkotika dan prekursor narkotika dapat ditangkap beserta barang bukti apa adanya. ${ }^{9}$ Penyerahan yang dibawah pengawasan menurut standar operasional

\footnotetext{
9 Petunjuk Lapangan No. Pol. Juklap/04/VIII/ 1983 tentang Taktik dan Teknik Pembelian Narkotika Psikotropika dan Teknik Penyerahan Narkoba Yang Dikendalikan (Controlled Delivery).
} 
penyidikan oleh Bareskrim yaitu berupa penyamaran untuk dapat mengikuti/ melibatkan diri dalam pendistribusian narkotika sampai kepada tempat tertentu yang hanya dilakukan petugas Polri tertentu. ${ }^{10}$ Penyerahan dibawah pengawasan (control delivery) sebagai salah satu metode yang digunakan penyidik menurut Petunjuk Lapangan Kapolri Nomor Polisi: Juklap/03/VIII/1993 tentang taktik dan penyerahan di bawah pengawasan menyebutkan teknik ini merupakan suatu teknik khusus dalam penyidikan kejahatan narkotika tahap penyelidikan dan terjadi penangguhan/penangkapan/penahanan/penyitaan barang bukti, yang dimana seorang tersangka yang mau bekerja sama dengan polisi atau informan atau pejabat lain (undercover agent) dibenarkan/narkotika tersebut pada penerimanya, dengan maksud pada saat penerimaan dapat ditangkap orang-orang yang terlibat kejahatan narkotika beserta barang buktinya. ${ }^{11}$ Jadi, penyerahan tersebut terjadi dalam keadaan dimana seseorang menyerahkan sesuatu kepada orang lain, dan diawasi yang berarti dilakukan pengawasan. Secara singkatnya keadaan seorang bandar atau pengedar atau yang menguasai narkotika menyerahkan barang narkotika kepada penyidik dengan alasan jual-beli, di mana dalam penyerahan narkotika tersebut berada dalam pengawasan penyidik yang sebelumnya telah menjadi sasaran penyidikan. Pelaksanaan teknik pembelian terselubung dan penyerahan dibawah pengawasan yang dilakukan dalam penyidikan tidak benar apabila tindakan yang diluar dari apa yang diatur dalam Perkap Polri, artinya tidak dibenarkan jika aparat kepolisian melakukan tindakan pembelian terselubung tanpa adanya perintah tertulis dari pimpinan. Perlu adanya perintah tertulis dari pimpinan menandakan bahwa tindakan pembelian terselubung dan penyerahan yang diawasi ini dilakukan secara resmi dan diketahui oleh pimpinan. Maka penyidik dapat ditindak dan dapat dijatuhkan sanksi sesuai dengan peraturan yang berlaku dalam pembelian terselubung. Hal tersebut sama dengan apa yang dikatakan dalam Undang-Undang Narkotika yang sama mengantongi surat perintah dari pimpinan sebelum melakukan teknik pembelian terselubung dan penyerahan yang diawasi.

\footnotetext{
10 Standar Operasional Prosedur Bareskrim Polri.

11 ibid.
} 


\section{Dampak Penggunaan Teknik Pembelian Terselubung dan Penyerahan Di Bawah Pengawasan}

Dalam proses penyidikan terdapat teknik khusus yang digunakan penyidik dalam melakukan penyidikan tindak pidana narkotika yaitu teknik pembelian terselubung dan teknik penyerahan dibawah pengawasan. Dasar hukum kedua teknik ini terdapat pada Pasal 75 huruf j Undang-Undang Nomor 35 Tahun 2009, yang dimana kedua teknik ini menjadi kewenangan dari BNN. Namun, Pasal 81 Undang-Undang Narkotika memberikan kewenangan kepada Polri untuk terlibat dalam melakukan penyidikan terhadap penyalahgunaan dan peredaran narkotika bersama Badan Narkotika Nasional (BNN). Polri dalam melakukan penyelidikan maupun penyidikan melihat pada Peraturan Kepala Kepolisian Negara Republik Indonesia Nomor 6 Tahun 2019. Dikaitkan dengan teknik pembelian terselubung dan teknik penyerahan dibawah pengawasan, berdasarkan Peraturan Kepala Kepolisian Negara Republik Indonesia Nomor 6 Tahun 2019 yang selanjutnya disebut Perkap Polri juga mengatur adanya teknik yang sama dengan teknik pembelian terselubung yaitu teknik penyamaran. ${ }^{12}$ Hal ini berdasarkan pada Pasal 6 Perkap Polri, dalam rangka kegiatan penyelidikan Polisi dapat melakukan kegiatan penyelidikan meliputi pengolahan TKP, pengamatan (observasi), wawancara (interview), pembuntutan (surveillance), penyamaran (undercover), pembelian terselubung (undercover buy), penyerahan di bawah pengawasan (control delivery), pelacakan (tracking), penelitian dan analisis dokumen. Dengan ditetapkannya ketentuanketentuan yang terkait mengenai teknik pembelian terselubung dan penyerahan dibawah pengawasan memberikan kepastian hukum bagi penyidik dalam menggunakan teknik penyidikan pembelian terselubung dan teknik penyerahan dibawah pengawasan. Kegiatan teknik pembelian terselubung dan penyerahan di bawah pengawasan dapat memenuhi unsur yuridis pada Pasal 50 KUHP, dimana kedua teknik ini menjadi alasan pembenar bagi penyidik. Alasan pembenar merupakan alasan yang menghapus sifat melawan hukum suatu tindak pidana yang

12 Sapto Winengku dan Umar Ma'ruf, 'Teknik Pembelian Terselubung Dalam Penyidikan Tindak Pidana Narkotika' (2017) 12 Hukum Khaira Ummah.[877]. 
dalam hal ini tindak pidana narkotika. Sehingga penyidik tidak dapat dikenakan sanksi pidana apapun dalam penggunaan kedua teknik ini. Namun disisi lain dapat menimbulkan kekhawatiran penyalahgunaan wewenang dan hak-hak sebagai tersangka dapat dilanggar. Mekanisme perlindungan hak-hak tersangka dapat dimulai dari rangka penyidikan hingga pengadilan. KUHAP menjamin tersangka untuk segera mendapat pemeriksaan dan diadili oleh Pengadilan. Mengingat kasus narkotika harus diutamakan. Hal ini tercantum dalam Pasal 50 ayat (1), (2), dan (3), dimana terdakwa bebas untuk menyangkal, memberikan keterangan secara bebas tanpa adanya tekanan dari berbagai pihak kepada hakim atau penyidik.

Dengan melihat teknik penyidikan pembelian terselubung dan penyerahan di bawah pengawasan yang subjektif, sehingga rawan sekali untuk timbul penyalahgunaan wewenang dari penyidik. Salah satu contoh penyalahgunaan yang berpotensi adalah proses tertib administrasi. Apabila proses ini terabaikan, hal ini dapat menimbulkan kerugian secara materiil maupun immateriil bagi masyarakat dan perorangan secara umum karena berkaitan dengan pengabaian kewajiban hukum dalam penyelenggaraan pelayanan publik yang diselenggarakan oleh Negara. Praktek pengabaian administrasi sering disebut dengan praktek maladministrasi. Praktek maladministrasi yaitu perilaku perbuatan melawan hukum, melampaui wewenang, menggunakan wewenang untuk tujuan lain dari wewenang tersebut, termasuk juga kelalaian dan pengabaian hal yang berkaitan dengan pelayanan publik oleh penyelenggaraan negara sehingga timbul kerugian secara materiil maupun immaterial. ${ }^{13}$ Sehingga mekanisme pengawasan secara internal dan eksternal sangat diperlukan dalam suatu lembaga. Pengawasan oleh atasan kepada bawahan dapat dikategorikan sebagai pengawasan internal. Tidak hanya pengawasan secara internal dari masing-masing institusi, peran serta masyarakat dalam pengawasan setiap kasus narkotika juga sangat dibutuhkan. Mengingat, banyaknya penyidik yang mendapat laporan dari masyarakat namun masyarakat tidak memiliki buktibukti yang cukup. Peran serta masyarakat dapat dikaitkan pada ketentuan Pasal

\footnotetext{
${ }^{13}$ Undang-Undang Republik Indonesia Nomor 37 Tahun 2008 tentang Ombudsman Repub-
} lik Indonesia. 
105 Undang-Undang Nomor 35 Tahun 2009 tentang Narkotika. Pasal 105 UndangUndang Nomor 35 Tahun 2009 tentang narkotika menyebutkan bahwa:

"Masyarakat mempunyai hak dan tanggung jawab dalam upaya pencegahan dan pemberantasan penyalahgunaan dan peredaran Narkotika dan Prekursor Narkotika". ${ }^{14}$

Sehingga Pasal 105 Undang-Undang Narkotika bertujuan untuk menjamin hak masyarakat dalammelakukan upaya pencegahan dan pemberantasan penyalahgunaan narkotika untuk ikut serta dengan cara mencari, memperoleh, bahkan memberikan informasi yang tidak diketahui oleh penyidik dalam penggunaan teknik penyidikan pembelian terselubung dan penyerahan dibawah pengawasan. Narkotika di satu sisi merupakan obat atau bahan yang memiliki manfaat dalam bidang medis namun di sisi lain dapat menimbulkan ketergantungan yang sangat merugikan apabila disalahgunakan dan tanpa pengawasan. Undang-Undang Narkotika menyebutkan bahwa teknik penyidikan pembelian terselubung dan teknik penyerahan di bawah pengawasan, sehingga kedua teknik ini sebagai bentuk urgensi untuk pengawasan terhadap penyalahgunaan dan prekursor narkotika.

\section{Kesimpulan}

Dasar pertimbangan dari penggunaan teknik penyidikan pembelian terselubung dan penyerahan dibawah bahwa pertimbangan hukum ditetapkannya teknik pembelian terselubung dan penyerahan di bawah pengawasan adalah untuk mempermudah proses penyidikan tindak pidana narkotika dan penuntutan terhadap orang-orang yang terlibat dalam kasus tindak pidana narkotika. Karena narkotika termasuk dalam suatu kejahatan yang serius dan terbilang cukup sulit pengungkapannya, Maka penggunaan teknik pembelian terselubung dan penyerahan di bawah pengawasan dapat menjadi dasar pertimbangan dalam penyidikan kasus tindak pidana. Implementasi dari penggunaan teknik penyidikan pembelian terselubung dan penyerahan di bawah pengawasan dilakukan oleh Polri dan BNN

\footnotetext{
${ }^{14}$ Undang-Undang Nomor 35 Tahun 2009 tentang Narkotika.
} 
di lapangan dengan melihat KUHAP dan petunjuk lapangan. Dampak yang muncul dari penggunaan teknik penyidikan pembelian terselubung dan penyerahan di bawah pengawasan meliputi dampak yuridis dan dampak sosial. Kekhawatiran oleh masyrakat kepada penegak hukum yang memiliki kewenangan untuk menggunakan teknik penyidikan pembelian terselubung dan penyerahan di bawah pengawasan meliputi praktek maladministrasi dan pelanggaran terhadap hak-hak tersangka. Sehingga adanya peran masyrakat dalam andil dalam pengawasan terhadap penegak hukum agar terciptanya proses hukum yang adil dan cepat. Pengawasan secara internal masing-masing institusi baik Badan Narkotika Nasional dan Polri harus diperketat agar dapat meminimalisir penyalahgunaan wewenang khususnya dalam penggunaan teknik penyidikan pembelian terselubung dan penyerahan di bawah pengawasan dalam administrasinya. Kesadaran masyarakat akan bahaya narkotika harus di tingkatkan agar dapat mempermudah penyelesaian suatu kasus narkotika dan terciptanya lingkungan di bawah pengaruh narkotika.

\section{Daftar Bacaan}

\section{Buku}

AR. Sujono dan Bony Daniel, Komentar \& Pembahasan Undang-Undang Nomor 35 Tahun 2009 tentang Narkotika, (Sinar Grafika 2011).

Hari Sasangka, Narkotika dan Psikotropika dalam Hukum Pidana (Mandar Maju 2003).

\section{Jurnal}

Ade Maria Engelina, 'Penerapan Pembelian Terselubung Dalam Penyelidikan Tindak Pidana Penyalahgunaan Narkotika Oleh Kepolisian Resor Siak', (2018) V JOM Fakultas Hukum.

Frans Simangunsong, 'Penegakan Hukum Terhadap Pelaku Tindak Pidana Narkotika (Studi Kasus di Kepolisian Resor Surakarta)' (2014) 8 Yuridika UNSA.

Heni Hendrawati dan Johny Krisnan, Nurwati, 'Analisis Penyidikan Tindak Pidana Penyalahgunaan Narkotika Dan Tindak Pidana Umum Dalam Kajian Perbandingan' (2019) IX Yuridika Universitas Muhammadiyah Purworejo. 
Riza Alifianto Kurniawan, 'Pencegahan Penyalahgunaan Kewenangan Penyidik Dalam Penegakan Hukum Tindak Pidana Narkotika' (2018) 47 MasalahMasalah Hukum.

Sapto Winengku dan Umar Ma'ruf, 'Teknik Pembelian Terselubung Dalam Penyidikan Tindak Pidana Narkotika' (2017) 12 Hukum Khaira Ummah.

\section{Laman}

Rini Friastuti, 'Mengenal Undercover Buying dan Control Delivery Dalam Penanganan Kasus Narkoba', (detikNews, 2016) <https://news.detik.com/ berita/d-3317950/mengenal-undercover-buying-dan-control-delivery-dalampenanganan-kasus-narkoba $>$.

\section{Perundang-undangan}

Undang-Undang Republik Indonesia Nomor 37 Tahun 2008 tentang Ombudsman Republik Indonesia

Undang-Undang Nomor 35 Tahun 2009 tentang Narkotika

Petunjuk Lapangan No. Pol. Juklap/04/VIII/ 1983 tentang Taktik dan Teknik Pembelian Narkotika Psikotropika dan Teknik Penyerahan Narkoba Yang Dikendalikan (Controlled Delivery) 